The Journal of Animal \& Plant Sciences, 30(3): 2020, Page: 742-748

ISSN (print): 1018-7081; ISSN (online): 2309-8694

\title{
A DEVELOPMENTAL STUDY OF A SOLAR-ASSISTED MAIZE DRYER FOR QUALITY DRYING
}

\author{
F. Hussain ${ }^{1}$, M. Ahmad ${ }^{1}$, A. Ghafoor ${ }^{1}$ and Asif Tanvir ${ }^{2}$ \\ ${ }^{1}$ Department of Farm Machinery and Power, Faculty of Agricultural Engineering \& Technology, University of \\ Agriculture Faisalabad, Pakistan \\ 2 Department of Agronomy, Faculty of Agriculture, University of Agriculture Faisalabad, Pakistan \\ Corresponding Author's Email: sfbukhari1987@yahoo.com
}

\begin{abstract}
This study was conducted for the design and development of solar assisted maize dryer to encounter the post-harvest losses. The development and experimental study was carried out in the Department of Farm Machinery and Power, University of Agriculture Faisalabad. The solar maize dryer consisted of a V-groove solar collector having $1.89 \mathrm{~m}^{2}$ collector area, drying chamber having diameter and height of $1.05 \mathrm{~m}$ and $0.6 \mathrm{~m}$ respectively. Three air ducts having diameter $0.15 \mathrm{~m}$ have been provided within the drying chamber for drying homogeneity. In each of the experiments, 100 $\mathrm{kg}$ of maize with the initial moisture content of $24 \%$ (on average basis) was dried to $14 \%$ final moisture content. The average increase in temperature at the collector was 10 to $15{ }^{\circ} \mathrm{C}$ more than ambient temperature. Solar assisted maize dryer and open sun drying took 9 hours and 4 days respectively to dry maize up to desired moisture level. The maize samples were evaluated for quality analysis after drying. The percent (\%) fats, carbohydrates, proteins and fiber ranged between $3.86-3.89 \%, 76.86-76.89 \%, 6.89-6.91 \%$ and $7.26-7.29 \%$ respectively. The breakeven analysis of the dryer showed that at 970 hours of working total revenue cost equals to the total cost of the dryer.
\end{abstract}

Keywords: Solar energy, collector, drying chamber, breakeven analysis.

https://doi.org/10.36899/JAPS.2020.3.0087

Published online March 25, 2020

\section{INTRODUCTION}

The global food demand is increasing steadily and food prices have reached unprecedented levels causing food insecurity especially in developing countries. In most of the developing countries postharvest losses are one of the major reasons for the food insecurity (Aulakh, 2013). A significant amount of agricultural produce is lost during post-harvest operations due to lack of knowledge, inadequate techniques and poor infrastructure for storage (FAO, 2014). These losses can be broadly categorized as weight loss, quality loss and nutritional loss. The magnitude of post-harvest losses varies greatly among different crops, area and economics. The overall global post-harvest losses of major cereal crops ranged between 20-25\% (Gustavsson, 2011). These losses occurred during harvesting, threshing, winnowing, drying, transportation and storage. On the other hand the post-harvest losses during harvesting ranged between 10 $15 \%$ that is mainly due to high moisture content at harvest. The amount of moisture contents in major cereal crops at harvest varies between $20-30 \%$ that allows rapid bacterial and fungal growth during preservation (Belessiotis and Delyannis, 2011; Shah, 2013). The basic requirement to overcome this problem is limiting the moisture content before preservation. Thus, agricultural products should be dried up to $12-14 \%$ moisture content (wet basis) according to the type of crop and storage time (Kenneth, 2013; Igbeka, 2013).

Therefore drying is critical step to reduce moisture content, maintain product quality, minimize storage losses and transportation cost (Abass et al. 2014). Drying involves the transfer of heat, mass and momentum. The moisture is vaporized and swept away from a solid surface of material by passing air through products (Can 2000). Natural or open sun drying of crop is traditional and economical method practiced in developing countries. The drying material is spread over the roof of house, mate or on the earth in open sun drying thus exposed to direct solar radiation and stirred many times in a day. However the natural drying is not recommended as it is weather dependent, require high labor, slow process, high drying cost and inferior quality of product (Abass et al. 2014).

Mechanical drying offers advantages over natural drying such as reduction in handling losses and control over drying air temperature. These dryers are efficient and remove moisture in a short time (Alavi et al. 2011). If pre-heated air is used the efficiency of dryers can be improved. Solar energy provides a means to heat up the air before entering the dryer. Pakistan is receiving an extensive amount of solar radiation throughout the year owing to its unique location. The average net available solar radiations ranged between $10-15 \mathrm{MJ} \mathrm{m}^{-2}$ day $^{-1}$, and the sunshine time period is $12 \mathrm{~h} /$ day from 
March to October in Pakistan (Munir et al. 2012). Thus, solar dryers are better option to dry agricultural products up to safe moisture contents. The previous literature revealed that drying time of most of the solar dryers observed to be high due to uneven distribution of air in drying chamber that results in higher drying time, lower performance, low quality and higher energy consumption (Roman et al. 2012).

Keeping in view the above problems of drying and inferior quality of cereals especially maize, the developmental study was carried out on solar assisted maize dryer for quality oriented product.

\section{MATERIALS AND METHODS}

Basic Design Theory of Solar Assisted Maize Dryer: By taking into account all facts and recommendations, the developmental study was initiated to evaluate the performance of the dryer. The considered design parameters, equations and calculations are shown in Table 2 .

Description of Solar Assisted Maize Dryer: The development of batch type solar maize dryer was carried out in the Department of Farm Machinery and Power, University of Agriculture, Faisalabad Pakistan. A schematic view of the dryer is shown in Figure 1. The dryer consisted of a heating source (collector), drying chamber, plenum chamber and air ducts for aiding drying homogeneity. The collector was provided to receive solar radiation directly from the sun to raise the ambient temperature. It was adjusted horizontally at an angling $32^{\circ} \mathrm{N}-\mathrm{S}$ according to longitude and latitude of experimental site to receive maximum solar radiation. The drying chamber was constructed to place the product for drying. It consisted of a plenum chamber to calm down the air coming from plenum chamber. Air distribution system consisted of three perforated ducts for air homogeneity within the drying chamber. The components and specifications of dryer pertinent parts are shown in Table. 2.

Experimental Procedure: The experiments on maize grain drying were carried out in month of October under local conditions of Pakistan. The samples of maize for drying were obtained from Agriculture farm of University of Agriculture Faisalabad, Pakistan. The dryer was operated under no load conditions for one hour to stabilize the temperature and air velocity within drying chamber. Then it was loaded with $100 \mathrm{~kg}$ maize grain at $24 \%$ moisture content to dry up to $14 \%$ moisture content at 8:00 am to 5:00 pm. Another sample was dried in open-air under the sun to compare the performance of the dryer. The weight loss during open sun and moisture contents were measured at one-hour interval. The dried samples of maize grain were collected and cooled to ambient temperature and sealed it in a plastic bag. The performance of the dryer was evaluated by drying rate and collector efficiency. Air velocity, ambient temperature, collector inlet and outlet temperature, dryer inlet and outlet temperature, solar radiation and relative humidity were measured using anemometer, pyranometer, humidity meter and thermocouples.

Quality Analysis: The maize samples were dried up to desired moisture level, later evaluated for proximate analysis using standard methods recommended by AOAC (2000).

Cost Analysis of Dryer: The economic analysis was made on maize dryer based on information gathered from an experimental study. The methodology followed in this study was presented by Kenneth and Tommy (1987). Table 3. Shows the worksheet for calculating the cost analysis of dryer.

Table 1. Solar-assisted dryer design parameters and equations used for their calculation.

\begin{tabular}{|c|c|c|c|}
\hline Parameter & Equation & Results & Source \\
\hline Amount of water to be removed $(\mathrm{kg})$ & $M_{\mu}=\frac{W(M-M)}{}$ & 13.63 & Henderson and Perry (1980) \\
\hline Average drying rate $\left(\mathrm{kg}_{\mathrm{w}} \mathrm{h}^{-1}\right)$ & $\mathrm{m}_{\mathrm{dr}=} \frac{m^{1}}{t}-M$ & 1.15 & Tonui et al. (2014) \\
\hline Amount air needed for drying $(\mathrm{kg})$ & $m=\frac{m}{\Delta w * n}$ & 9086.6 & Ichsani and Dyah (2002) \\
\hline Volumetric flow rate, $\mathrm{V}_{\mathrm{a}}\left(\mathrm{m}^{3} \mathrm{~s}^{-1}\right)$ & $\mathrm{M}_{\mathrm{v}}=\mathrm{m}_{\mathrm{a}}^{* W} \mathrm{v}_{\mathrm{s}}^{* n}$ & 0.2442 & Axtell (2002) \\
\hline Total useful energy, Q (MJ) & $\mathrm{Q}=\mathrm{M}_{\mathrm{w}} \mathrm{L}+\mathrm{Mh}_{\mathrm{fg}}$ & 18.51 & Iodo et al. (2002) \\
\hline Collector area, $\mathrm{Ac}\left(\mathrm{m}^{2}\right)$ & $\mathrm{Q}=\mathrm{A}_{\mathrm{c}}\left(\mathrm{I}_{\mathrm{t}} \delta_{\mathrm{a}}\right)-\mathrm{U}_{\mathrm{L}}\left(\mathrm{T}_{\mathrm{p}}-\mathrm{T}_{\mathrm{a}}\right) \mathrm{F}_{\mathrm{R}}$ & 1.89 & Exell (1980) \\
\hline Fan capacity (hp) & $\mathrm{Hp}=\frac{Q * S}{3}$ & 0.75 & Ashfaq et al. (2016) \\
\hline Dryer efficiency & $\eta=\frac{m^{3} c(T 2-T 1)}{l}$ & $<35 \%$ & Ashfaq et al. (2016) \\
\hline
\end{tabular}

Variation of Temperature and Solar Intensity: The performance of the dryer was evaluated by conducting a series of experiments on maize. The variation of solar radiation, relative humidity and ambient temperature during experiment are shown in fig. 2 for typical days of October 2017 in Faisalabad. The mean values of ambient temperature, solar radiation and relative humidity during experiment observed to be 28.5 to $35.3^{\circ} \mathrm{C}, 680-840 \mathrm{~W} / \mathrm{m}^{2}$ 
and $71-43 \%$ respectively. The highest curve of ambient air temperature and solar radiation were observed at 1:00 $\mathrm{pm}$. On the other hand, the relative humidity was found to be low with the increase in ambient temperature. It was observed that dryer inlet temperature was $10-15^{\circ} \mathrm{C}$ more than ambient temperature that increased the drying rate of maize within the drying chamber (Agbossou et al. 2016).

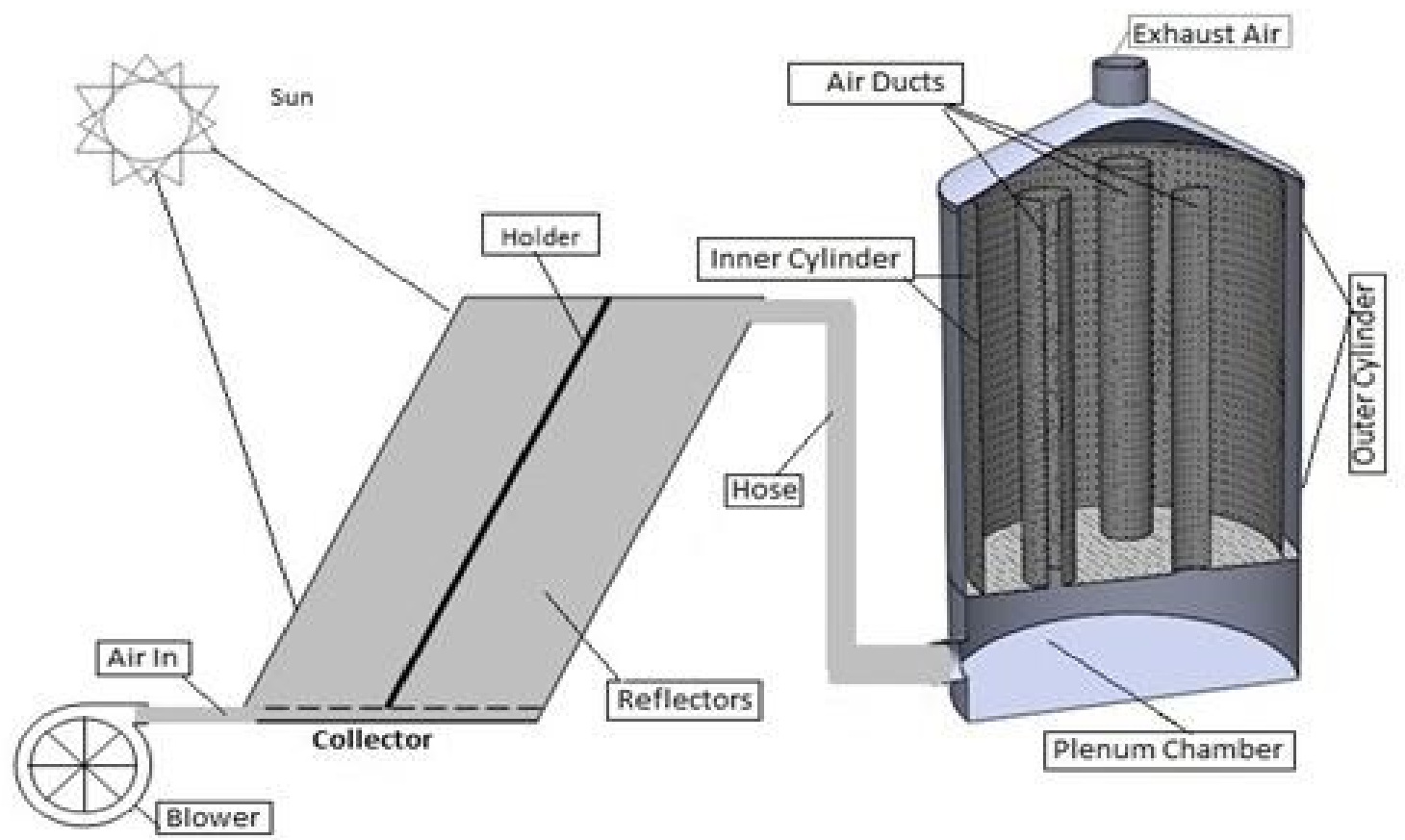

Figure. 1. Schematic diagram of a batch type solar assisted maize dryer.

Table 2. Design specifications and assumption of maize dryer

\begin{tabular}{lll}
\hline Components & $\begin{array}{l}\text { Conditions \& Specifications } \\
\text { of dryer }\end{array}$ \\
\hline 1. Solar collector & V-groove solar collector \\
a. Type & $1.89 \mathrm{~m}^{2}$ \\
b. Area & Transparent Glass $5 \mathrm{~mm}$ thick \\
c. Covering & $80 \%$ \\
d. Transmittance & $2 \mathrm{~mm}$ \\
e. Absorber Plate & \\
& thickness & $32^{\circ} \mathrm{N}-\mathrm{S}$ (horizontal) \\
f. Collector tilt & Polystyrene $50 \mathrm{~mm}$ thick \\
g. Insulation & \\
2. Drying chamber & \\
a. Diameter & $1.050 \mathrm{~m}$ \\
b. Height & $0.6 \mathrm{~m}$ \\
c. Volume & $0.138 \mathrm{~m}^{3}$ \\
d. Type & Perforated $3 \mathrm{~mm}$ \\
3. Air distribution & \\
& \\
a. System & Diameter & $0.150 \mathrm{~m}$ \\
b. Height & $0.6 \mathrm{~m}$ \\
c. No of ducts & 3 \\
d. Perforation & $3 \mathrm{~mm}$ \\
4. Blower & $0.75 \mathrm{hp}$ \\
\hline &
\end{tabular}

Table 3. Worksheet of economic analysis of dryer.

\begin{tabular}{|c|c|c|}
\hline Cost & Parameters & Formulae \\
\hline \multirow[t]{7}{*}{$\begin{array}{l}\text { Capital } \\
\text { cost }\end{array}$} & Depreciation & $\begin{array}{l}\text { Rate } \times \text { (Purchase price- Salvage } \\
\text { value) }\end{array}$ \\
\hline & Interest on & (Current rate-Inflation rate) \\
\hline & avg. & $\times \begin{array}{llll}\mathrm{P} & \mathrm{p} & +\mathrm{S} & \mathrm{v} \\
\end{array}$ \\
\hline & investment & 2 \\
\hline & Insurance & $0.5 \% \times \frac{\mathrm{P}}{-} \quad \mathrm{p} \quad-\mathrm{S}$ \\
\hline & $\begin{array}{l}\text { Repairs } \\
\text { Total fixed } \\
\text { cost }\end{array}$ & $3 \% \times$ Purchase price ${ }^{2}$ \\
\hline & $\begin{array}{l}\text { Total capital } \\
\text { cost }\end{array}$ & $\begin{array}{l}\text { Total fixed cost/Annual unit } \\
\text { dried }\end{array}$ \\
\hline \multirow[t]{2}{*}{$\begin{array}{l}\text { Variable } \\
\text { cost }\end{array}$} & $\begin{array}{ll}\text { Energy } & \text { cost } \\
\text { per } & \text { unit } \\
\text { dried } & \end{array}$ & Total energy cost/Units dried \\
\hline & $\begin{array}{l}\text { Per unit } \\
\text { labor cost }\end{array}$ & $\begin{array}{l}\text { Hourly labor rate } \times \text { Hourly } \\
\text { drying rate }\end{array}$ \\
\hline $\begin{array}{l}\text { Total } \\
\text { drying } \\
\text { cost }\end{array}$ & Sum & $\begin{array}{l}\text { Fixed or capital cost }+ \text { Variable } \\
\text { cost }\end{array}$ \\
\hline
\end{tabular}




\section{RESULTS AND DISCUSSION}

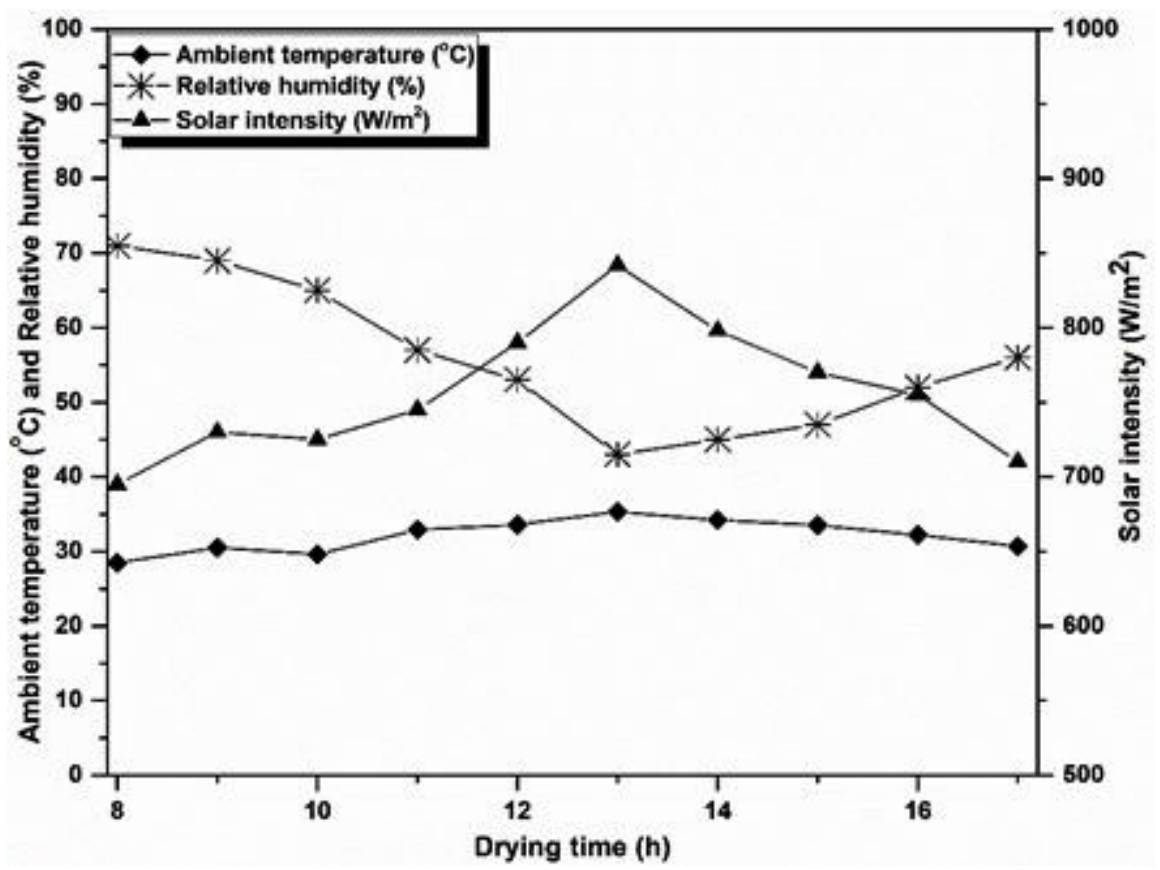

Figure.2. Shows ambient air temperature, relative humidity and solar radiation during experiments Variation of Temperature within the Dryer

The changing curves of mean ambient, solar maize dryer inlet, middle and outlet temperature are shown in the fig. 3. The ambient and dryer inside temperature showed continuously changing behavior from morning to evening with solar intensity. It was investigated that dryer temperature was higher than ambient temperature. The maximum temperature at collector and dryer inlet was recorded $52.3^{\circ} \mathrm{C}$ at $1: 00 \mathrm{pm}$ which was $47.3 \%$ more than ambient temperature $\left(35.3^{\circ} \mathrm{C}\right)$ at the same time. However, the average increase in dryer temperature was observed to be $45.8 \%$ as compared to ambient temperature. The increase in temperature was owing to solar collector that received direct solar radiation and increases the temperature of air moving to the dryer inlet (Ashfaq et al. 2016; Vijaykumar et al. 2012).

Variation of Relative Humidity within Dryer: The fig. 4 shows the mean difference of relative humidity of ambient air and solar assisted maize dryer inlet, middle and outlet. The relative humidity of air reduced continuously at dryer inlet from morning to noon and then increased up to evening due to variation of solar radiation and ambient temperatures. As the air moved through drying bed the relative humidity increased significantly with time until the maize reached desired moisture content. This may be due to increase in temperature at solar collector. The average relative humidity of the ambient, dryer inlet and outlet varied between $66-43 \%, 43-22 \%$ and $65-43 \%$. The difference in relative humidity implicated higher drying rates in the dryer (Arun et al. 2014).

Comparison of Moisture Content of Maize in Solar Dryer and Open Sun: The pattern of moisture removal from maize grain is shown in fig. 5. The drying process took place in three stages i.e. initial adjustment period, constant rate period and falling rate period. Initially, the free water was removed from the grain followed by the bound water. The graph shows that the sample exhibited a falling rate period that is true for most cereal crops. Previous literature revealed that drying in falling rate period mainly caused by diffusion mechanism. However, the drying in a constant rate period is dependent on external factors like air velocity, temperature and relative humidity. As there is no resistance to mass transfer in constant rate period. Thus, the drying time of the maize was reduced by the variation of these parameters (Ajadi and Sanusi, 2013; Putra and Ajiwiguna, 2017). Figure. 5 shows the comparison of moisture contents of maize dryer and open sun drying of the grain during experimental. The maize grain having average initial moisture contents of $24 \%$ were dried up to final moisture contents of $14 \%$ in 9 hours of continuous working of the dryer. However, the open sun drying took 4 days to achieve desired moisture content. It can be seen from results that the solar assisted maize dryer dried the maize earlier than open sun drying thus proved more efficient than open sun drying. 
Fig 5. shows varying profiles of dryer efficiency with solar radiation during experimental hours. It is clear from the graph that the drying efficiency increased gradually up to $1: 00 \mathrm{pm}$ and then reduced with a decrease in solar radiation thus increased the drying rate of maize sample. The maximum and minimum efficiency of the dryer during typical experimental days was found to be $28 \%$ and $21 \%$ at $8: 00$ am and $1: 00$ pm respectively.

Quality Analysis: The determination of proximate and mineral element compositions of maize products provided substantive nutritional information on maize. The moisture content of the maize and its products in the current study was consistent and slightly higher than the earlier research on maize products. The slight variation in proximate analysis may be attributed due to the maize variety used, environmental factors and agronomic practices (Trabelsi et al. 1998). The maize was dried for 9 hours and evaluated for fats, carbohydrates, proteins and fiber contents determination. Table. 4 shows percent contents of maize dried using solar assisted maize dryer.

Economic Analysis: The drying cost Comparison showed that drying cost of solar maize dryer proves to be more economical as compared to open sun drying. The literature reviewed showed that cost of drying maize in open sun was $0.0197 \$ / \mathrm{kg}$, while solar assisted dryer was $0.0123 \$ / \mathrm{kg}$. The breakeven analysis for the dryer payback period is shown in Fig. 7 by the intersection of two lines. The point shows that the payback period of the maize dryer is $970 \mathrm{~h}$. The dryer will run free of cost after the payback period. Table 5. Shows the economic analysis of solar maize dryer in American dollars (\$).

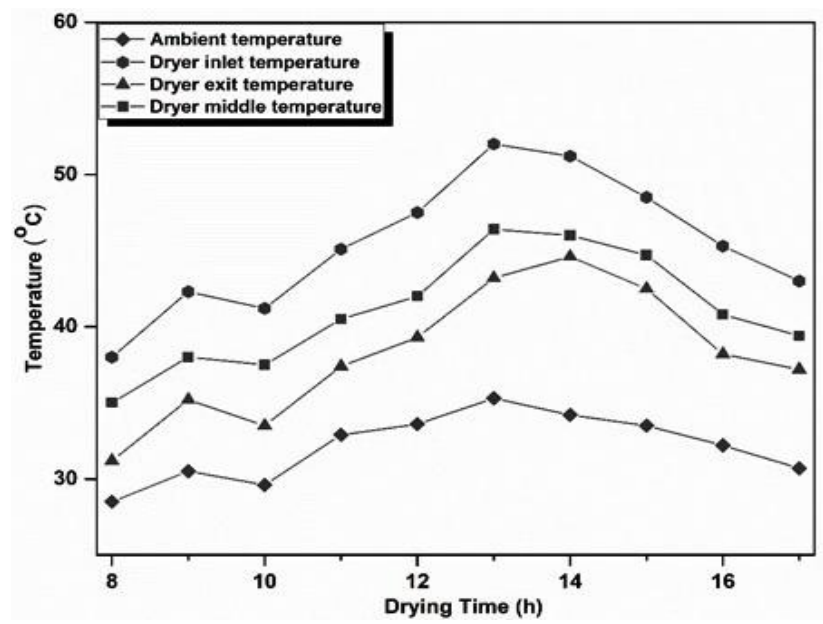

Figure.3. Variation of mean ambient and dryer inlet, middle and outlet temperature during experiments

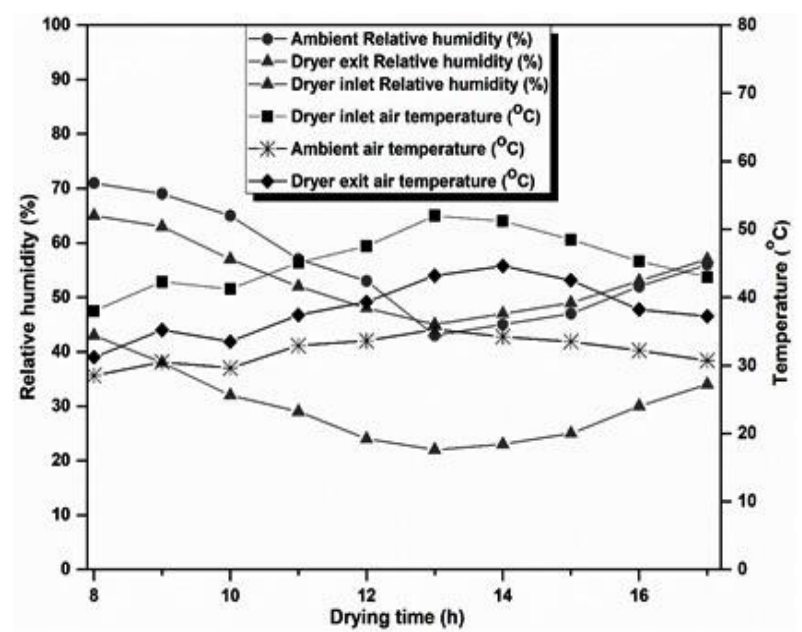

Figure. 4. Variation of mean drying temperature and relative humidity of solar assisted maize dryer. Dryer Efficiency

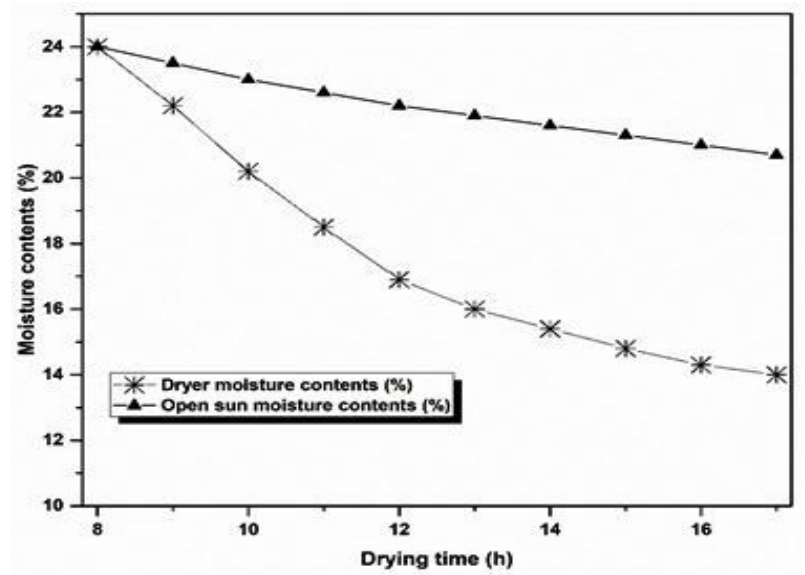

Figure 5. Comparison of moisture loss in open sun and maize dryer

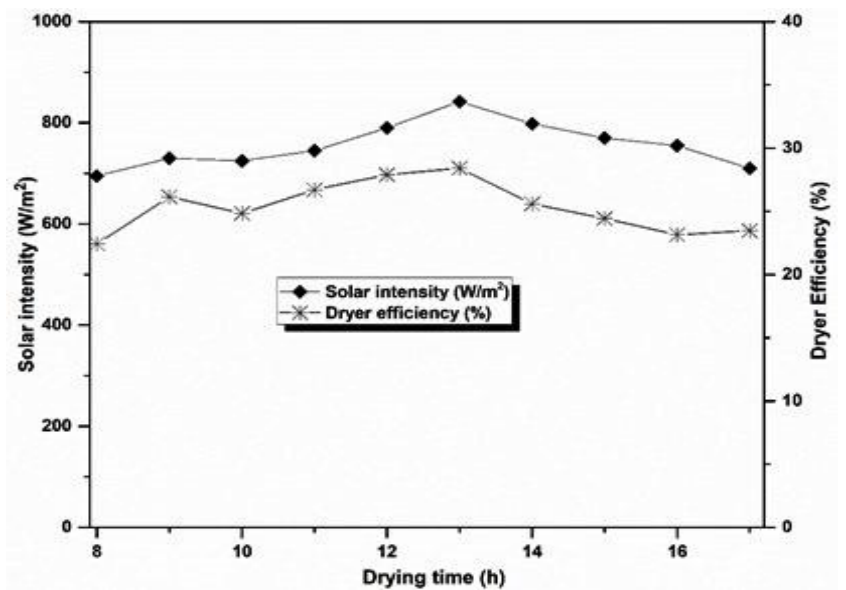

Figure 6. Shows dryer efficiency vs solar radiation during typical experimental days 
Table 4. Quality analysis of maize dried in solar assisted maize dryer.

\begin{tabular}{lc}
\hline Quality parameters & Percent Contents (\%) \\
\hline Fats & $3.86-3.89$ \\
Carbohydrate & $76.86-76.89$ \\
Protein & $6.89-6.91$ \\
Fiber & $7.26-7.29$ \\
\hline
\end{tabular}

Table 5. Worksheet of calculated economic analysis parameters of solar assisted maize dryer.

\begin{tabular}{|c|c|c|}
\hline Cost & Parameters & Values (\$) \\
\hline \multirow{6}{*}{ Capital cost } & Depreciation & 35.52 \\
\hline & $\begin{array}{l}\text { Interest on avg. } \\
\text { investment }\end{array}$ & 17.36 \\
\hline & Insurance & 8.88 \\
\hline & Repairs & 11.84 \\
\hline & Total fixed cost & 73.61 \\
\hline & Total capital cost & $0.0040 \$ / \mathrm{kg}$ \\
\hline \multirow[t]{3}{*}{ Variable cost } & $\begin{array}{l}\text { Energy cost per unit } \\
\text { dried }\end{array}$ & $0.0047 \$ / \mathrm{kg}$ \\
\hline & Per unit labor cost & $0.0035 \$ / \mathrm{kg}$ \\
\hline & Total drying cost & $0.0123 \$ / \mathrm{kg}$ \\
\hline
\end{tabular}

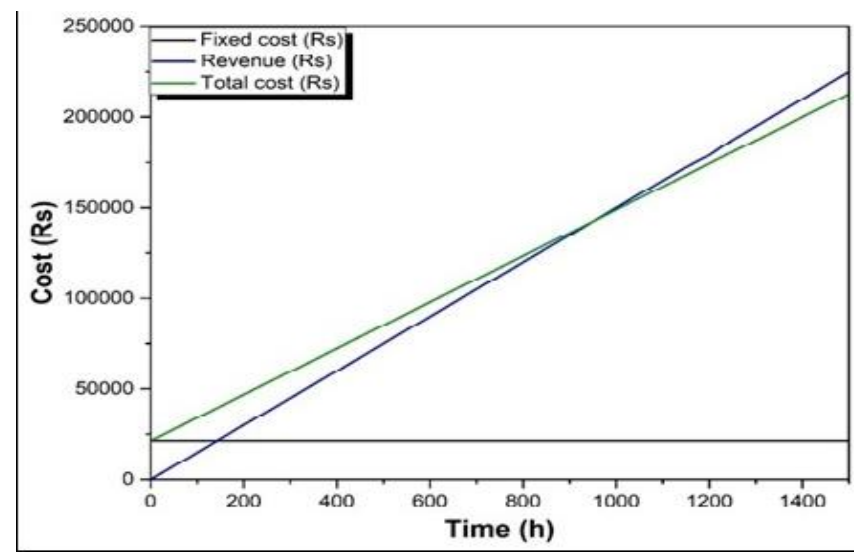

Figure 7. Break even analysis of solar assisted maize dryer

Conclusion: The experiments for drying of maize in maize dryer were conducted during the month of October 2017 for evaluating the performance of the dryer. The full-scale tests of $100 \mathrm{~kg}$ maize grain were conducted in the solar maize dryer. The initial moisture contents of $24 \%$ (on average basis) were reduced to $14 \%$ in 9 hours that was lesser than open sun drying that took 4 days to dry up to the same final moisture content. The difference between drying time of both drying methods was because of high temperature and low relative humidity prevailed inside solar assisted maize. The percent (\%) fats, carbohydrates, proteins and fiber ranged between 3.86$3.89, \quad 76.86-76.89, \quad 6.89-6.91$ and $7.26-7.29 \%$ respectively. The performance and quality analysis of the dryer revealed that solar assisted maize dryer helpful for small scale farmers to reduce post-harvest losses and quality oriented maize products.

Acknowledgements: The authors would like to thank for financial support by office of Research, Innovation and Commercialization (ORIC) and Department of Farm Machinery \& Power, University of Agriculture Faisalabad, Pakistan.

\section{REFERENCES}

Abass, A.B., G. Ndunguru, P. Mamiro, B. Alenkhe, N. Mlingi, and M. Bekunda. (2014). Post-harvest food losses in a maize-based farming system of semi-arid savannah area of Tanzania. J. Stored Prod. Res. (57) 49-57.

Agbossou, K., K. Napo, and S. Chakraverty. (2016). Mathematical modelling and solar tunnel drying characteristics of yellow maize. American J. of Food Sci. and Technol. 4(4): 115-124.

Ajadi, D.A. and Y.K. Sanusi. (2013). Effect of relative humidity on oven temperature of locally design solar cabinet dryer. Global. J. Inc. (USA). 13(1).

Alavi, H.R., A. Htenas, R. Kopicki, A.W. Shepherd, and R. Clarete. (2011). Trusting trade and the private sector for food security in south-east Asia. World bank publications washington DC, USA.

Arun, S., K. Velmurugan, and S.S. Balaji. (2014). Experimental studies on drying characteristics of coconuts in a solar tunnel greenhouse dryer. Int. J. of Innovative Technol. and Exploring Eng. 4(5): 51-11.

Ashfaq, S., M. Ahmad, and A. Munir. (2016). Design, development and performance evaluation of a small-scale solar assisted paddy dryer for on farm processing. Mehran University Research J. of Eng. and Technol. 35(2): 217.

Aulakh, J., A. Regmi, J.R. Fulton, and C. Alexander. (2013). Estimating post-harvest food losses: Developing a consistent global estimation framework. In Proc. of the Agricultural and Applied Economics Association's (AAEA) and CAES Joint Annual Meeting, Washington DC, USA.

Axtell, B. (2002). Back matter drying food for profit: Drying food for profit: A guide for Small Businesses. Practical Action Publishing. 75p.

Belessiotis, V. and E. Delyannis. (2011). Solar drying. Solar energy. 85: 1665-1691.

Can, A. (2000). Drying kinetics of pumpkin seeds. Int. J. of energy research. 24 (11): 965-975.

Exell, R.H.B. (1980). Basic design theory for a simple solar rice dryer. Int. Energy. J. 1(2).

Food and Agriculture Organization of United Nations. (2014). Global initiative on food losses and waste reduction (FAO) Rome, Italy. 
Gustavsson, J., C. Cederberg, U. Sonesson, R.V. Otterdijk, and A. Meybeck. (2011). Global food losses and food waste. Food and Agriculture Organization of the United Nations: Rome, Italy.

Henderson, S.M., and R.L. Perry. (1980). Agricultural Process Engineering. John Wiley and Sons. Inc, London. 303-335p.

Horwitz, W. (2000). Official methods of analysis of AOAC International. 1. AOAC International, Gaithersburg, Md.

Ichsani, D., and W.A. Dyah. (2002). Design and experimental testing of a solar dryer combined with the kerosene stoves to dry fish. American Society of Agric. and Biol. Eng. (5): 1-3.

Igbeka, J. (2013). Agricultural processing and storage engineering. 1st Ed. Ibadan Univ. press.

Iodo, I.N., S.E. Obetta, and A.A. Satimehin. (2002). Evaluation of a solar crop dryer for rural applications in Nigeria. Botswana. J. of Technol. 11(2): 58-62.

Kenneth, J.P. (2013). Grain drying. NDSU (North Dakota State University) service. Fargo, North Dakota.

Kenneth, J.H., and R. Tommy. (1987). Calculating grain drying cost. NDSU Extension Services, North Dakota State, University of Agriculture and Applied Science, AE 923.

Munir, A., U. Amman, U.S. Muhammad, I. Muhammad and A. Manzoor. (2012). Performance evaluation and simulation of a photovoltaic powered water pumping system. Pakistan J. Life. Soc. Sci. 10 (2): 166-171.

Putra, R. N., and T. A. Ajiwiguna. (2017). Influence of air temperature and velocity for drying process. Procedia. eng. (170): 516-519.

Román, F., V. Strahl-Schafer, and O. Hensel. (2012). Improvement of air distribution in a fixed-bed dryer using computational fluid dynamics. Biosystems engineering. 112(4): 359-369.

Shah, D. (2013). Assessment of Pre and Post-Harvest Losses in Tur and Soyabean Crops in Maharashtra. Agro-Economic Research Centre Gokhale Institute of Politics and Economics: Pune, India.

Tonui, K.S., Mutai, E.B.K., Mutuli, D. A., Mbuge, D. O., \& Too, K. V. (2014). Design and evaluation of solar grain dryer with a back-up heater. Res. J. Appl. Sci. Engg. Technol. 7(15): 3036-3043.

Trabelsi, S., A.W. Kraszewski, and S.O. Nelson. (1998). Nondestructive microwave characterization for determining the bulk density and moisture content of shelled corn. Measurement Sci. and Technol. 9(9): 1548-1556.

Vijaykumar. P., S.R. Desai, Lokesh, and M. Anatachar. (2012). Performance evaluation of solar tunnel dryer for chilli drying. Karnataka j. Agric. Sci. 25(4): (472-474). 